\title{
MENINGKATKAN MOTIVASI DAN HASIL BELAJAR MATEMATIKA DENGAN MENGGUNAKAN MODEL REALISTIC MATHEMATICS EDUCATION (RME) MATERI HIMPUNAN
}

\author{
Heni Tusdia \\ IKIP Siliwangi, Jl. Terusan Jendral Sudirman, Cimahi Tengah, Kota Cimahi, Jawa Barat \\ tusdiaheni@gmail.com
}

\begin{abstract}
This study aims to see the changes that occur from the motivation and student learning outcomes by using the Realistic Mathematics Education (RME) model of the set material in class VII-G students of SMP Negeri 1 Cisarua. The population used in this study were students of class VII-G SMP Negeri 1 Cisarua as many as 34 students consisting of 14 male students and 20 female students. The method used in this research is classroom action research which is divided into 3 (three) cycles. In this case the overall cycle can be obtained that the motivation and student learning outcomes by using the Realistic Mathematics Education (RME) model of the material set for students of class VII-G SMP Negeri 1 Cisarua can increase.
\end{abstract}

Keywords: Realistic Mathematics Education (RME), Set, Motivation and student learning.

\begin{abstract}
Abstrak
Penelitian ini bertujuan untuk melihat perubahan yang terjadi dari motivasi dan hasil belajar siswa dengan menggunakan model Realistic Mathematics Education (RME) terhadap materi himpunan pada siswa kelas VIIG SMP Negeri 1 Cisarua. Populasi yang digunakan dalam penelitian ini adalah siswa kelas VII-G SMP Negeri 1 Cisarua sebanyak 34 siswa yang terdiri dari 14 siswa laki-laki dan 20 siswa perempuan. Metode yang digunakan dalam penelitian ini adalah penelitian tindakan kelas (PTK) yang terbagi menjadi 3 (tiga) siklus. Dalam hal ini secara keseluruhan siklus dapat diperoleh bahwa motivasi dan hasil belajar siswa dengan menggunakan model Realistic Mathematics Education (RME) terhadap materi himpunan pada siswa kelas VIIG SMP Negeri 1 Cisarua dapat meningkat.
\end{abstract}

Kata kunci: Realistic Mathematics Education (RME), Himpunan, Motivasi belajar, Hasil belajar siswa.

Mata pelajaran matematika merupakan pelajaran yang diajarkan mulai dari tingkat Sekolah Dasar sampai ke tingkat Perguruan Tinggi dan digunakan dalam ehidupan sehari-hari (Akbar, 2018; Bungsu, 2019; Bernard, 2019; Sugandi, 2019). Itu membuktikan bahwa matematika memiliki peran yang sangat penting dalam perkembangan dunia pendidikan sampai saat ini. Selain itu juga pentingnya peranan matematika terlihat dari pengaruh konsep yang kita peroleh dari pembelajaran matematika terhadap mata pelajaran yang lainnya (Isnaeni, 2019), contohnya mata pelajaran fisika, kimia, geografi. Pada pelajaran fisika dan kimia, konsep matematika digunakan untuk mempermudah dalam proses turunan rumus-rumus yang dipelajari. Sedangkan pada pelajaran geografi, konsep matematika digunakan untuk menghitung perbandingan atau skala dalam pembuatan peta (Karim, 2011) dan dapat dikatakan bahwa matematika merupakan pelayan ilmu (Wiliawanto, 2019).

Di dalam proses pelajaran matematika tingkat SMP, siswa belajar mengenai bahasan materi himpunan yang merupakan materi yang baru bagi siswa SMP kelas VII. Menurut Sukiman, dkk (2009) himpunan adalah sekumpulan objek yang mempunyai syarat tertentu dan jelas (Murniasih, 2016). Objek yang dimaksud dapat berupa bilangan, manusia, hewan, tumbuhan, negara dan sebagainya. Objek ini selanjutnya dinamakan anggota atau elemen dari himpunan itu. Syarat tertentu dan jelas dalam menentukan anggota suatu himpunan ini sangat penting karena untuk membedakan mana yang menjadi anggota himpunan dan mana yang bukan merupakan anggota himpunan. Melalui penjelasan tersebut, 
maka materi himpunan dapat dikatakan sangat penting bagi siswa untuk dipelajari dan dimengerti.

Tetapi pada kenyataannya, masih banyak siswa yang mendapatkan nilai rendah yaitu dibawah nilai Kriteria Ketuntasan Minimal (KKM) setelah mengerjakan evaluasi atau tes mengenai materi himpunan. Hal tersebut terjadi pula di SMP Negeri 1 Cisarua. Beberapa penyebabnya yaitu kurangnya motivasi belajar siswa, siswa kurang aktif dalam kegiatan pembelajaran, siswa sulit menguasai materi, dan rendahnya kemampuan dasar siswa tertutama tentang materi himpunan. Menurut Sutrisno, 1998 (Lasati, 2006), pembelajaran matematika selama ini pada umumnya kurang memberikan kesempatan kepada siswa untuk mengembangkan kemampuan berfikir strategis sehingga siswa hanya menghapalkan saja semua rumus atau konsep tanpa memahami maknanya dan tidak mampu menerapkannya dalam berbagai situasi aplikatif (Chotimah, 2019; Insani, 2019) dan belum memahami simbol matematika (Bernard, et. al, 2019), padahal siswa membutuhkan suatu konsep sautu kunci untuk mengembangkan kognitif (Bernard \& senjayawati, 2019)

Pendekatan Realistic Mathematics Education (RME) merupakan suatu pendekatan yang berasumsi perlu adanya pengaitan antara matematika dengan realitas yang ada dan dapat dijumpai dalam kehidupan sehari-hari (Sopyan, 2019). Hans Freudenthal mengemukakan bahwa "matematika merupakan suatu bentuk aktivitas manusia (mathematic as human activities)", pernyataan tersebut yang menjadi landasan dalam pengembangan Pendidikan Matematika Realistik (Realistic Mathematics Education). Pada pembelajaran Realistik tidak sekedar menunjukkan adanya hubungan dengan dunia nyata namun lebih menekankan pada suatu situasi yang dapat dibayangkan siswa sehingga mempermudah siswa dalam memahami pembelajaran yang diberikan (Syamsudin dkk, 2018).

Oleh karena itu, pendekatan RME dapat menjadi solusi dalam meningkatkan motivasi dan hasil belajar siswa pada materi himpunan. Hal tersebut didasarkan pada pengertian bahwa model pendekatan RME dapat dijumpai dalam kehidupan sehari-hari, sehingga mempermudah siswa dalam memahami konsep mengenai materi himpunan, yang berakibat pada motivasi dan pencapaian hasil belajar siswa meningkat.

\section{METODE}

Penelitian ini merupakan penelitian tindakan kelas (PTK) karena penelitian ini dilaksanakan sesuai dengan langkah-langkah PTK yaitu mulai dari tahap perencanaan, implementasi, observasi, dan refleksi. Subjek penelitian ini adalah siswa kelas VII-G SMP Negeri 1 Cisarua sebanyak 34 siswa yang terdiri dari 14 siswa laki-laki dan 20 siswa perempuan. Penelitian ini dilaksanakan 26 November 2019 sampai 10 Oktober 2019. Pengambilan data dilakukan selama 3 kali pertemuan dengan alokasi waktu 90 menit per pertemuan. Pengambilan data tersebut terdiri dari data tertulis tes dan data observasi berupa kuesioner. Subjek penelitian ini dikatakan tuntas belajar apabila mendapatkan nilai minimal 70 (KKM). Penelitian ini terdiri dari 3 siklus yaitu siklus I, siklus II dan siklus III. Masing-masing siklus mengikuti langkah-langkah penelitian tindakan kelas sebagai berikut: 


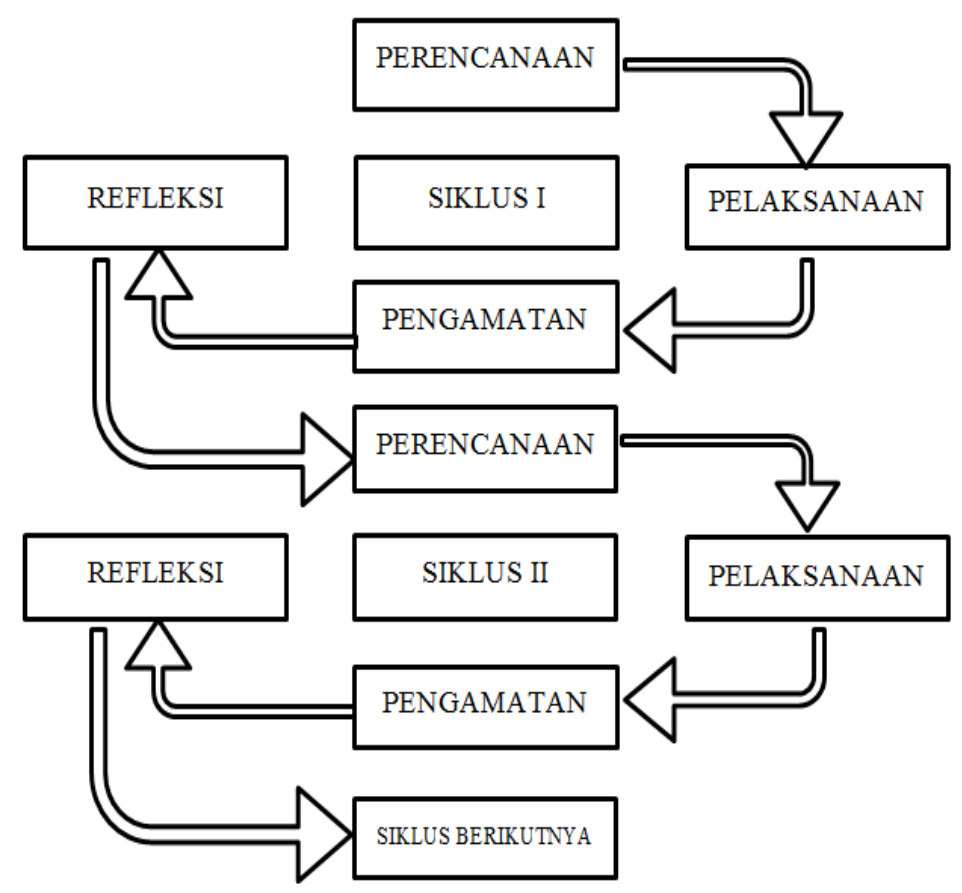

Gambar 1. Penelitian Tindakan dari Kemmis dan McTaggart

\section{HASIL}

Keseluruhan hasil pembelajaran dari siklus I sampai dengan siklus III dapat menyatakan bahwa motivasi dan hasil belajar siswa dengan menggunakan model Realistic Mathematics Education (RME) terhadap materi himpunan kelas VII-G di SMP Negeri 1 Cisarua terjadi peningkatan, dengan penjelasan melalui tabel dan gambaran data hasil keseluruhan siklus berikut :

\section{Tabel 1.}

Motivasi Belajar

\begin{tabular}{|c|c|c|c|}
\hline Motivasi Belajar & Siklus I & Siklus II & Siklus III \\
\hline $\begin{array}{c}\text { Tidak ada minat terhadap bermacam-macam } \\
\text { masalah matematika (-) }\end{array}$ & $\begin{array}{c}29 \text { Siswa } \\
(85,29 \%)\end{array}$ & $\begin{array}{c}16 \text { Siswa } \\
(47,05 \%)\end{array}$ & $\begin{array}{c}6 \text { Siswa } \\
(17,64 \%)\end{array}$ \\
\hline \multirow{2}{*}{ Cepat bosan pada tugas-tugas rutin (-) } & 25 Siswa & 14 Siswa & 7 Siswa \\
& $(73,52 \%)$ & $(41,17 \%)$ & $(20,58 \%)$ \\
\hline \multirow{2}{*}{ Dapat mempertahankan pendapatnya (+) } & 4 Siswa & 15 Siswa & 30 Siswa \\
& $(11,76 \%)$ & $(44,11 \%)$ & $(88,23 \%)$ \\
\hline \multirow{2}{*}{ Adanya hasrat dan keinginan berhasil (+) } & 7 Siswa & 22 Siswa & 29 Siswa \\
& $(20,58 \%)$ & $(64,70 \%)$ & $(85,29 \%)$ \\
\hline
\end{tabular}

Berdasarkan Tabel 1 diperoleh bahwa motivasi belajar siswa mengalami perubahan di setiap siklus yaitu dari indikator 1) tidak ada minat terhadap bermacam-macam masalah matematika yaitu dari 85,29\% menjadi 17,64\%,2) Cepat bosan pada tugas-tugas rutin yaitu dari 73,52\% menjadi 20,58\%, 3) Dapat mempertahankan pendapatnya dari 11,76\% menjadi 88,23\% ,4) Adanya hasrat dan keinginan berhasil dari $20,58 \%$ menjadi $85,29 \%$. 


\section{Tabel 2.}

Hasil Belajar Siswa

\begin{tabular}{|c|l|l|l|}
\hline $\begin{array}{c}\text { Hasil Belajar Siswa } \\
(\text { KKM })\end{array}$ & Siklus I & Siklus II & Siklus III \\
\hline Di atas Nilai KKM & $\begin{array}{l}4 \text { Siswa } \\
(11,76 \%)\end{array}$ & $\begin{array}{l}15 \text { Siswa } \\
(44,11 \%)\end{array}$ & $\begin{array}{l}23 \text { Siswa } \\
(67,64 \%)\end{array}$ \\
\hline
\end{tabular}

Berdasarkan Tabel 2 diperoleh bahwa hasil belajar siswa mengalami perubahan di setiap siklus dengan meningkatnya rata-rata KKM yaitu dari indikator yaitu dari $11,76 \%$ menjadi $67,64 \%$. Berdasarkan hasil penelitian di atas, maka Model Realistic Mathematics Education (RME) terhadap materi himpunan dapat meningkatkan motivasi dan hasil belajar siswa. Hal tersebut dapat terlihat dari hasil perubahan motivasi belajar dan hasil belajar siswa yang memiliki nilai di atas KKM mengalami peningkatan yaitu pada siklus I ada 4 siswa $(11,76 \%)$, siklus II ada 15 siswa $(44,11 \%)$ dan siklus III ada 23 siswa $(67,64 \%)$.

\section{KESIMPULAN}

Berdasarkan hasil analisa dan pembahasan, maka dapat disimpulkan bahwa motivasi dan hasil belajar siswa dengan menggunakan model Realistic Mathematics Education (RME) terhadap materi himpunan kelas VII-G di SMP Negeri 1 Cisarua dapat meningkat. Hal itu diketahui dari hasil menurunnya motivasi belajar yang negatif yaitu sikap tidak ada minat terhadap bermacam-macam masalah matematika dari $85.29 \%$ menjadi $17.64 \%$ dan sikap cepat bosan pada tugas-tugas rutin dari $73.52 \%$ menjadi $20.58 \%$. sedangkan motivasi belajar siswa yang positif berhasil meningkat yaitu dapat mempertahankan pendapatnya dari $11.76 \%$ menjadi $88.23 \%$ dan adanya hasrat dan keinginan berhasil dari $20.58 \%$ menjadi $85.29 \%$. Selain itu juga terjadi peningkatan dari hasil belajar siswa yaitu peningkatan jumlah siswa yang memperoleh hasil nilai di atas nilai KKM dari 4 Siswa $(11.76 \%)$ menjadi 23 Siswa $(67.64 \%)$.

\section{DAFTAR PUSTAKA}

Akbar, P., Hamid, A., Bernard, M., \& Sugandi, A. I. (2018). Analisis kemampuan pemecahan masalah dan disposisi matematik siswa kelas xi sma putra juang dalam materi peluang. Jurnal Cendekia: Jurnal Pendidikan Matematika, 2(1), 144-153.

Bernard, M., \& Senjayawati, E. (2019). Developing the Students' Ability in Understanding Mathematics and Self-confidence with VBA for Excel. JRAMathEdu (Journal of Research and Advances in Mathematics Education), 1(1), 45-56.

Bernard, M., \& Senjayawati, E. (2019). Meningkatkan Kemampuan Koneksi Matematik Siswa SMP dengan Menggunakan Pendekatan Metaphorical Thinking Berbantuan Software Geogebra. Jurnal Mercumatika: Jurnal Penelitian Matematika dan Pendidikan Matematika, 3(2), 79-87. 
Bernard, M., Akbar, P., Ansori, A., \& Filiestianto, G. (2019, October). Improve the ability of understanding mathematics and confidence of elementary school students with a contextual approach using VBA learning media for Microsoft Excel. In Journal of Physics: Conference Series (Vol. 1318, No. 1, p. 012035). IOP Publishing.

Bernard, M., Sumarna, A., Rolina, R., \& Akbar, P. (2019, October). Development of high school student work sheets using VBA for microsoft word trigonometry materials. In Journal of Physics: Conference Series (Vol. 1315, No. 1, p. 012031). IOP Publishing.

Bungsu, T. K., Vilardi, M., Akbar, P., \& Bernard, M. (2019). Pengaruh Kemandirian Belajar Terhadap Hasil Belajar Matematika Di Smkn 1 Cihampelas. Journal on Education, 1(2), 382-389.

Chotimah, S., Ramdhani, F. A., Bernard, M., \& Akbar, P. (2019). Pengaruh Pendekatan Model-Eliciting Activities Terhadap Kemampuan Berpikir Kritis Matematik Siswa Smp Negeri Di Kota Cimahi. Journal on Education, 1(2), 68-77.

Insani, S. U., \& Akbar, P. (2019, October). Development of Open-Ended Based Mathematics Problem to Measure High-Level Thinking Ability. In Journal of Physics: Conference Series (Vol. 1315, No. 1, p. 012047). IOP Publishing

Isnaeni, S., Ansori, A., Akbar, P., \& Bernard, M. (2019). Analisis Kemampuan Koneksi Matematis Siswa Smp Pada Materi Persamaan Dan Pertidaksamaan Linear Satu Variabel. Journal on Education, 1(2), 309-316.

Karim, A. (2011). Penerapan metode penemuan terbimbing dalam pembelajaran matematika untuk meningkatkan pemahaman konsep dan kemampuan berpikir kritis siswa sekolah dasar. Jurnal pendidikan, 1(1), 21-32.

Lasati, D. (2006). Efektivitas Pendekatan Realistic Mathematics Education (RME) pada Pembelajaran Persamaan Garis Lurus Siswa SMP Nasional KPS Balikpapan. Jurnal Pendidikan Inovatif, 1(2), $20-23$.

Luthfia, L., Prasetyo, Y., Triawan, E., Hanifan, M., Anwar, R., \& Hidayat, W. (2019). Penerapan Mode1 Pembelajaran Example Non Example Matematika Untuk Meningkatkan Motivasi Siswa. Journal on Education, 1(3), 87-93.

Murniasih, T. R., Ferdiani, R. D., \& Fayeldi, T. (2016). Media smart diagram venn untuk meningkatkan pemahaman konsep siswa pada materi himpunan. Math Didactic, 2(2), 70-76.

Sopyan, R., Dewi, M. K., Fauzan, G. A., \& Bernard, M. (2019). Penerapan Pendekatan Realistic Mathematic Education Untuk Meningkatkan Konsep Diri (Self Concept) Siswa SMP di Era Milenial. Journal on Education, 2(1), 45-42.

Sugandi, A. I., \& Akbar, P. (2019). Efektivitas Penerapan Strategi React Terhadap Kemampuan Koneksi Matematis dan Self-Efficacy Siswa SMP. Jurnal Cendekia: Jurnal Pendidikan Matematika, 3(2), 431-436.

Syamsudin, N., Afrilianto, M., \& Rohaeti, E. E. (2018). Meningkatkan Kemampuan Komunikasi Matematik Siswa Kelas VIII SMP Negeri 2 Cariu pada Materi Sistem Persamaan Linier Dua 
Variabel dengan Pendekatan Realistic Mathematic Education (RME). JPMI (Jurnal Pembelajaran Matematika Inovatif), 1(3), 313-324.

Wiliawanto, W., Bernard, M., Akbar, P., \& Sugandi, A. I. (2019). Penerapan Strategi Pembelajaran Aktif Question Student Have Untuk Meningkatkan Kemampuan Berpikir Kritis Matematik Siswa SMK. Jurnal Cendekia: Jurnal Pendidikan Matematika, 3(1), 139-148. 